\title{
Variability in dimethylsulfoniopropionate (DMSP) concentrations in Spartina alterniflora and the effect on Littoraria irrorata
}

\author{
Whitney M. Kiehnn ${ }^{1, *}$, James T. Morris ${ }^{2}$ \\ ${ }^{1}$ Marine Sciences Program and Belle W. Baruch Institute, and ${ }^{2}$ Department of Biology and Belle W. Baruch Institute, \\ University of South Carolina, Columbia, South Carolina 29208, USA
}

\begin{abstract}
We measured concentrations of dimethylsulfoniopropionate (DMSP) in Spartina alterniflora (Loisel.) in response to the plant hormones abscisic acid (ABA), jasmonic acid (JA), and salicylic acid (SA) to determine whether DMSP concentration is linked to any of their signaling pathways. DMSP concentrations were also measured in plants at a salt marsh dieback site in Georgetown County, South Carolina (USA), to determine whether dieback conditions affect foliar DMSP concentrations. We found elevated levels of DMSP in plants receiving SA treatment compared to a control treatment, but we found no treatment effect for either of the other 2 hormone treatments. This suggests that DMSP production or transformation is linked to the SA signaling pathway. Diminished levels of DMSP were observed in plants nearest the dieback edge compared to those farthest from the dieback in an apparently healthy marsh, which suggests that DMSP concentration responds to environmental conditions connected with salt marsh dieback. Using a ring assay, we found that Littoraria irrorata snails, potential herbivores of $S$. alterniflora, were attracted to DMSP. However, we found no correlation between DMSP concentration and $L$. irrorata density at the acute dieback site. These results suggest that factors such as plant biomass may play a more important role than DMSP in determining $L$. irrorata distribution in dieback areas.
\end{abstract}

KEY WORDS: Stress hormone $\cdot$ Attractant $\cdot$ Deterrent $\cdot$ Salt marsh dieback

\section{INTRODUCTION}

Dimethylsulfoniopropionate (DMSP) is a tertiary sulfonium compound produced by marine algae (Karsten et al. 1990) and by some higher plant species, including the salt marsh cordgrass Spartina alterniflora (Loisel.) (Dacey et al. 1987). Average concentrations of DMSP in S. alterniflora on the east coast of North America range from 9 to $70 \mu \mathrm{mol} \mathrm{^{-1 }}$ fresh weight (Dacey et al. 1987, Otte \& Morris 1994, Colmer et al. 1996), and values up to $250 \mu \mathrm{mol} \mathrm{g} \mathrm{g}^{-1}$ dry weight have been reported for greenhouse plants (Otte \& Morris 1994). DMSP has a variety of functions in marine algae, including that of an osmoregulatory compound, cryoprotectant (Karsten et al. 1990), sulfide detoxification molecule (Van Diggelen et al. 1986), herbivore deterrent (Wolfe et al. 1997), and antioxidant (Sunda et al.
2002). Until recently, the role of DMSP in S. alterniflora has been unclear. Work by Husband \& Kiene (2007) showed that dimethylsulfoxide (DMSO), an oxidative product of DMSP and dimethylsulfide (DMS), occurs in leaves, stems, and roots of $S$. alterniflora and has a greater relative concentration than DMSP in roots and yellowing leaves where oxidative stress can be high. The results of Husband \& Kiene (2007) suggest that DMSP concentrations in $S$, alterniflora change in response to stress.

In addition to having an antioxidant function, DMSP in Spartina alterniflora may affect herbivore behavior. While investigating the effects of long-term nitrogen fertilization on $S$. alterniflora plots at Goat Island, North Inlet, South Carolina, USA (Morris et al. 2002, Sundareshwar et al. 2003), Morris and co-workers observed that plants in fertilized plots were grazed 
more frequently by rice rats Oryzomys palustris compared to plants in unfertilized plots. They observed that the rats had chewed through the sheath of the stem in order to reach the younger shoots inside. Upon further analysis, the investigators found that the inner tissue of the stems that the rice rats were probably trying to reach contained a much lower concentration of DMSP than the same tissue from the unfertilized plants (Otte et al. 2004). These observations, along with others (Dacey \& Wakeham 1986, Nakajima 1989, Wolfe \& Steinke 1996, Wolfe et al. 1997, Van Alstyne \& Houser 2003), suggest that DMSP may act as an herbivore deterrent. Attractant properties of DMSP have also been observed. Van Alstyne et al. (2001) demonstrated that DMSP can act as a feeding attractant for the purple sea urchin Strongylocentrotus purpuratus and the green sea urchin Strongylocentrotus droebachiensis. DMSP is also a foraging cue for certain species of planktivorous reef fishes (DeBose et al. 2008). DMSP released during algal grazing by zooplankton allows fishes to 'eavesdrop on trophic interactions' (DeBose et al. 2008) by recognizing that the presence of residual DMSP is an indication of prey presence. In a similar way, DMSP produced by $S$. alterniflora or ephiphytic algae growing on $S$. alterniflora and marsh substrate may act as a foraging or orientation cue for herbivores, enabling them to identify potential food or refugia.

The objective of this investigation was to determine whether DMSP concentrations in Spartina alterniflora change in response to environmental conditions and whether those changes may affect herbivore behavior. Both greenhouse and field studies were used to address this objective. In the greenhouse study, $S$. alterniflora plants were exposed to 1 of 3 stress-inducing plant hormones (abscisic acid, $\mathrm{ABA}_{i}$ jasmonic acid, $\mathrm{JA}_{\text {; }}$ or salycilic acid, SA) or to a control solution, and DMSP concentration was subsequently measured. ABA concentration responds to a variety of environmental stressors such as drought and high salinity and can signal physiological stress responses to cope with these stressors (Mizrahi et al. 1970, Zabadal 1974). JA belongs to a family of plant bio-regulating compounds known as jasmonates, which might play a key role in plant responses to herbivores and pathogens and are involved in major signaling pathways for plant defense (Farmer \& Ryans 1990). SA is important in plant growth and development and is recognized as an endogenous signal for mediating plant defense to pathogens and for disease resistance (White 1979, Antoniw \& White 1980, Wieringa-Brants \& Schets 1988, Ward et al. 1991, Shah 2003). SA can also be important in the thermotolerance (Dat et al. 1998, 2000, LopezDelgado et al. 1998), thermogenicity (Raskin et al. 1987, 1989), and oxidative stress tolerance (Fodor et al. 1997, Rao et al. 1997, Dat et al. 1998, 2000, Srivastava
\& Dwivedi 1998, Larkindale \& Knight 2002) of certain plants; SA is also directly involved in physiological responses in salt and osmotic stress in plants (Borsani et al. 2001). ABA, SA, and jasmonates have been used in previous studies to induce a variety of stress responses (Mizrahi et al. 1970, Bradford 1983, Creelman \& Mullett 1995, Senaratna et al. 2000). We hypothesized that DMSP concentrations in plants sprayed with the control solution would differ significantly from those sprayed with hormone-containing solutions.

In the field portion of the experiment, Spartina alterniflora plants were sampled at an acute dieback site along 3 transects between the dieback edge and healthy marsh. Salt marsh dieback, also known as brown marsh, is characterized by the loss of aboveground vegetation and affects a variety of plants including $S$. alterniflora. While the cause of marsh dieback is still debated, it is often associated with drought conditions which can lead to increased physiological stress on the plants (McKee et al. 2004, Ogburn \& Alber 2006). Runaway grazing by the snail Littoraria irrorata following such physiological stress may also be a contributing factor to salt marsh dieback (Silliman et al. 2005). Because we expected DMSP concentration to respond to dieback conditions, we hypothesized that foliar concentrations of DMSP at the dieback edge would be significantly different from those in apparently healthy marsh. We also hypothesized that DMSP would deter periwinkle snails and that snail density would therefore correlate negatively with DMSP concentration. To test the deterrent hypothesis, both laboratory and field studies were performed. A ring assay and field data collected at an acute dieback site at North Inlet Estuary, Georgetown County, South Carolina, were used to test the hypothesis that DMSP would deter periwinkle snails.

\section{MATERIALS AND METHODS}

Hormone exposure. Short-form Spartina alterniflora plants were collected during summer 2007 from Oyster Landing in the North Inlet Estuary salt marsh in Georgetown County and were maintained in the greenhouse for about 4 mo prior to the experiment. Three individually potted plants ranging in height from about 35 to $50 \mathrm{~cm}$ were used for each treatment $\left(\mathrm{N}=3, \mathrm{~N}_{\text {total }}=12\right)$. Plants were thoroughly sprayed (about $5 \mathrm{ml} \mathrm{plant}^{-1}$ ) with 1 of 3 solutions containing plant hormones or a control solution. Hormonecontaining solutions contained either $40 \mu \mathrm{M}$ ABA (MP Biomedicals LLC $;$ as in Mizrahi et al. 1970), $50 \mu \mathrm{M}$ SA (Baker; as in Senaratna et al. 2000), or $500 \mu \mathrm{M} \mathrm{JA}$ (Sigma; as in Creelman \& Mullett 1995), Triton X-100 (final concentration $0.01 \% \mathrm{v} / \mathrm{v}$ ), and ethanol (final con- 
centration $0.1 \% \mathrm{v} / \mathrm{v}$; as in Bradford 1983). The control solution contained similar concentrations of Triton X100, ethanol, and water only. Test and control solutions were applied once daily for 3 consecutive days. Approximately $6 \mathrm{~h}$ after the last treatments on the third day, the top 2 leaves from each plant were harvested and stored at $-80^{\circ} \mathrm{C}$ until DMSP analysis.

All data analyses were performed using the SPSS 14.0 statistical package for Windows. Data collected during the $\mathrm{ABA}, \mathrm{JA}$, and SA exposure experiment were analyzed using Model I analysis of variance (ANOVA) followed by Bonferroni and Ryan-EinotGabriel-Welsch $F$ (REGW F) tests for post hoc multiple comparisons $(\alpha=0.05)$. Leaf position (first or second from top) was not a significant factor ( $p>0.300)$; therefore, DMSP concentrations for the 2 leaves were averaged and analyzed as a single value for each plant.

Dieback transects. Aboveground plant biomass, Littoraria irrorata density, and foliar concentrations of DMSP were measured along 3 transects at an acute dieback site located at $33^{\circ} 19^{\prime} 20.50^{\prime \prime} \mathrm{N}, 79^{\circ} 11^{\prime} 4.23^{\prime \prime} \mathrm{W}$ in North Inlet Estuary during May (spring) and June (early summer) 2006. Death of aboveground vegetation was first observed in 2002, following a period of extreme drought (www.ncdc.noaa.gov/oa/climate/ research/drought/palmer-maps/), and had begun to revegetate by 2006. Transects ranged in length from 12 to $20 \mathrm{~m}$ and extended from the dieback edge outward toward apparently healthy marsh (Fig. 1b). Plant biomass data, snail density data, and plant samples for DMSP analysis were collected using $35 \times 35 \mathrm{~cm}$ quadrats at $4 \mathrm{~m}$ intervals along each transect. Because the transect angle relative to the dieback edge was different for each transect and the dieback morphology was asymmetrical, the distance of individual quadrats from the dieback edge was measured and is considered a semi-random variable. Additionally, 8 non-transect quadrats located either inside the dieback edge ( $\mathrm{N}=2$; at 2 and $3 \mathrm{~m}$ from the dieback edge) or at least $20 \mathrm{~m}$ from the dieback edge in apparently healthy marsh $(\mathrm{N}=6)$ were sampled. The average distance for the outermost non-transect quadrats was $24 \mathrm{~m}$ and is represented as such in the data analyses.

Three to 5 Spartina alterniflora leaves were collected from separate plants within each sampling quadrat for DMSP analysis, depending on the number of green plants in each sampling quadrat. To control for plant age, leaves similar in position on each plant (second leaf from the top) were harvested. Leaves were stored on ice until transported to the laboratory, where they were stored at $-80^{\circ} \mathrm{C}$ until they were analyzed for DMSP. All standing live and dead $S$. alterniflora were clipped at the marsh surface with shears, and all dead material longer than $\sim 2$ to $3 \mathrm{~cm}$ was also collected from the marsh surface. However, plants inside the dieback were not harvested so as not to disturb the recovery of the dieback site. All live Littoraria irrorata snails found on plants or on the marsh surface within each quadrat were collected into individual plastic containers and counted. Snails and plants were transported to the lab where they were rinsed and then dried at $60^{\circ} \mathrm{C}$ to a constant weight.

DMSP concentrations measured in leaves of individual plants within a single quadrat ( $\mathrm{N}=3$ to 5$)$ were averaged and represent a single value in the statistical analyses. Correlation analysis of distance from the dieback edge, average DMSP concentration, snail density, snail density:plant biomass, and plant biomass

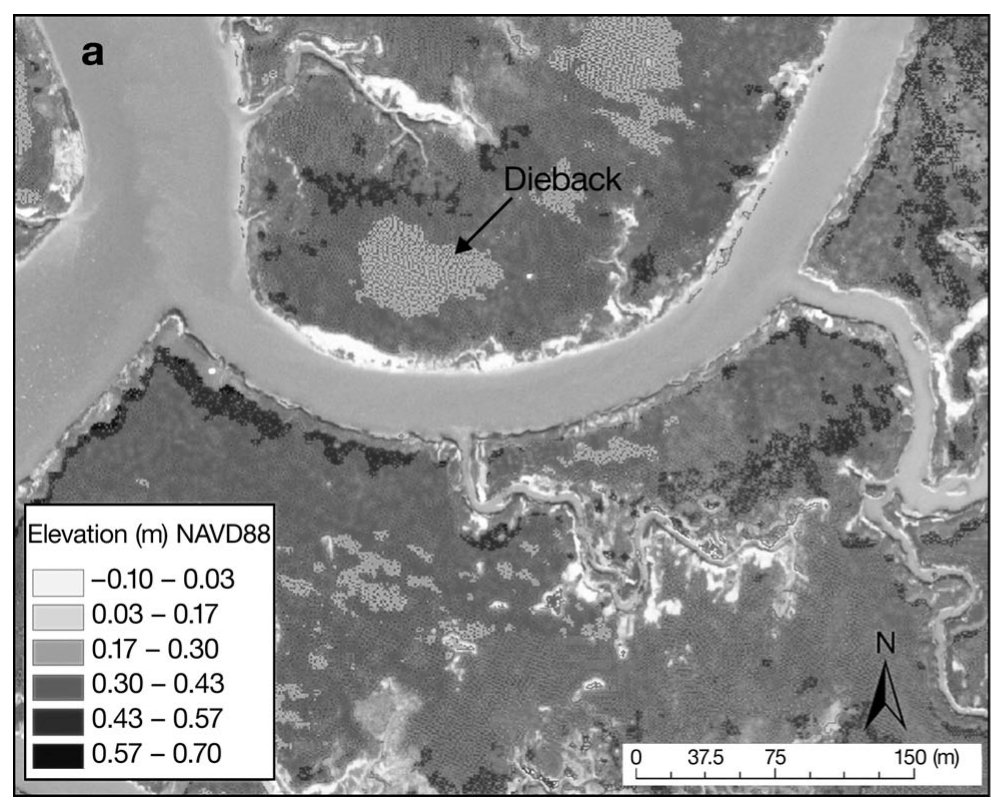

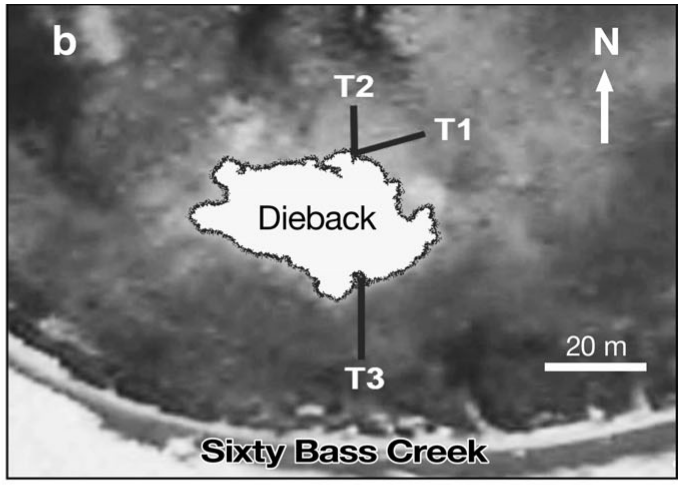

Fig. 1. Dieback site showing (a) relative elevation of dieback site and surrounding marsh and (b) location of 3 transects (T1, T2, and T3) extending from the dieback edge into apparently healthy marsh 
were carried out using Spearman's rank order analysis ( $\alpha=0.05$ ). A Model I least-squares linear regression analysis $(\alpha=0.05)$ was used to determine the model equation for variables distance and average DMSP concentration, which was calculated for individual quadrats.

We measured pore water chloride concentrations at the dieback and 2 healthy marsh sites, Goat Island and Oyster Landing, in North Inlet Estuary between October 2006 and December 2008 at a depth of 10, 25, and $50 \mathrm{~cm}$. These data were analyzed using a Model I ANOVA followed by a Bonferroni post hoc multiple comparisons test and were blocked by depth $(\alpha=0.05)$.

DMSP analysis. Analysis of DMSP in Spartina alterniflora was performed using methods modified from Van Diggelen et al. (1986) and Otte \& Morris (1994). Freshly thawed plant leaves were cut into 0.5 to $1 \mathrm{~cm}$ long pieces, weighed, and placed in $35 \mathrm{ml}$ gas-tight vials with $5 \mathrm{ml} 4.25 \mathrm{M} \mathrm{NaOH}$ solution. Vials were immediately capped with Teflon-lined butyl septa (Wheaton) and aluminum crimp caps. Standards were made with known amounts of DMSP. DMSP was synthesized as a hydrochloride salt using methods modified from Chambers et al. (1987) and was subsequently analyzed using proton nuclear magnetic resonance spectroscopy and determined to be at least $98 \%$ pure (services kindly provided by the University of South Carolina Magnetic Resonance Facility). Samples and standards were incubated in the dark at room temperature $\left(\sim 24^{\circ} \mathrm{C}\right)$ for at least $16 \mathrm{~h}$ (Otte \& Morris 1994).

Following incubation, vial headspace was analyzed for DMS gas by injecting $10 \mu \mathrm{l}$ of headspace into a Varian CP-3800 gas chromatograph (GC) using a $25 \mu \mathrm{l}$ gas-tight syringe. The GC was equipped with a flame ionization detector and a CP-Porabond Q capillary column $(0.32 \mathrm{~mm} \times 25 \mathrm{~m})$. Nitrogen was used as a carrier gas at a flow rate of $30 \mathrm{ml} \mathrm{min} \mathrm{mith}^{-1}$ a total column flow of $3 \mathrm{ml} \mathrm{min}{ }^{-1}$. The column oven was maintained at a starting temperature of $100^{\circ} \mathrm{C}$ for $2 \mathrm{~min}$ and then elevated at a rate of $15^{\circ} \mathrm{C} \mathrm{min}{ }^{-1}$ to a final temperature of $165^{\circ} \mathrm{C}$. DMS retention time was $5.2 \mathrm{~min}$.

Ring assay. Littoraria irrorata snails were gathered during February 2007 from North Inlet Estuary salt marsh and maintained in a clear plastic ventilated container with dead Spartina alterniflora plants for about $2 \mathrm{wk}$ prior to the ring assay experiment. For each treatment, 20 snails were used, and no snail was used more than once. DMSP was synthesized as a hydrochloride salt using the methods mentioned previously.

Snail response to DMSP was determined using a ring assay design modified from Duval et al. (1994). A $12.5 \mathrm{~cm}$ diameter filter paper (Whatman no. 1) was wetted with a control solution, and a $9 \mathrm{~cm}$ diameter donut-shaped ring of filter paper wetted with the test solution was laid on top. Control tests were carried out using the same control solution on both the background and ring filter papers. The control/background solution was prepared by adding $\mathrm{HCl}$ to distilled $\mathrm{H}_{2} \mathrm{O}$ until pH 2.6 was reached. Tris buffer was then added to adjust the solution $\mathrm{pH}$ to between 6.5 and 6.6. Ring solutions for the 10 and $90 \mu \mathrm{mol}$ DMSP ml ${ }^{-1}$ tests were prepared by mixing crystalline DMSP with distilled $\mathrm{H}_{2} \mathrm{O}$, resulting in a solution of $\mathrm{pH}$ 2.6. Tris buffer was added to the solution until the $\mathrm{pH}$ reached 6.5. Red food dye was added to all ring solutions to make any diffusion or mixing of solutions visible.

Once the ring assay was set up, a single active snail was chosen from the holding container and placed at the center of the filter papers. Because of the strong response that periwinkles show to movement, snails were monitored and recorded remotely using a Logitech QuickCam Chat web camera. Each snail was observed until it reached the margin of outermost paper or for $10 \mathrm{~min}$, whichever time was shortest. Snail shell lengths were measured from the apex to the farthest point on the aperture to the nearest tenth of a millimeter using dial calipers. Video recordings of each snail were later reviewed and snail paths traced onto ring assay diagrams. The path length across the test ring was measured and recorded for each snail. If a snail crossed the test ring more than once, each crossing was considered 1 path and was measured individually. The variation in snail size was controlled for by normalizing snail path length by snail length. Responses upon encountering the ring were categorized as positive if the snail followed the ring at least 2 snail lengths, negative if the snail turned around or withdrew into its shell, or neutral if the snail maintained its path and moved directly over the test ring.

A chi-squared test was used to determine whether there was a significant relationship between DMSP concentration and the number of snails (of 20) that exhibited a positive, negative, or neutral behavior upon encountering the ring during the ring assay.

\section{RESULTS}

\section{Hormone exposure}

Foliar concentrations of DMSP in Spartina alterniflora varied significantly $\left(F_{3,8}=5.2, \mathrm{p}=0.027\right)$ by treatment (ABA, JA, SA, or control). Plants sprayed with SA contained significantly ( $\mathrm{p}<0.05$ ) higher DMSP concentrations than those sprayed with the ABA or control solutions, but contained concentrations of DMSP similar to those of plants sprayed with JA (REGW F, Fig. 2). Plants treated with SA had a mean DMSP concentration of $50.0 \pm 4.3 \mu \mathrm{mol} \mathrm{g}{ }^{-1}$ fresh weight (fw), and plants treated with JA had an average DMSP concentration of 


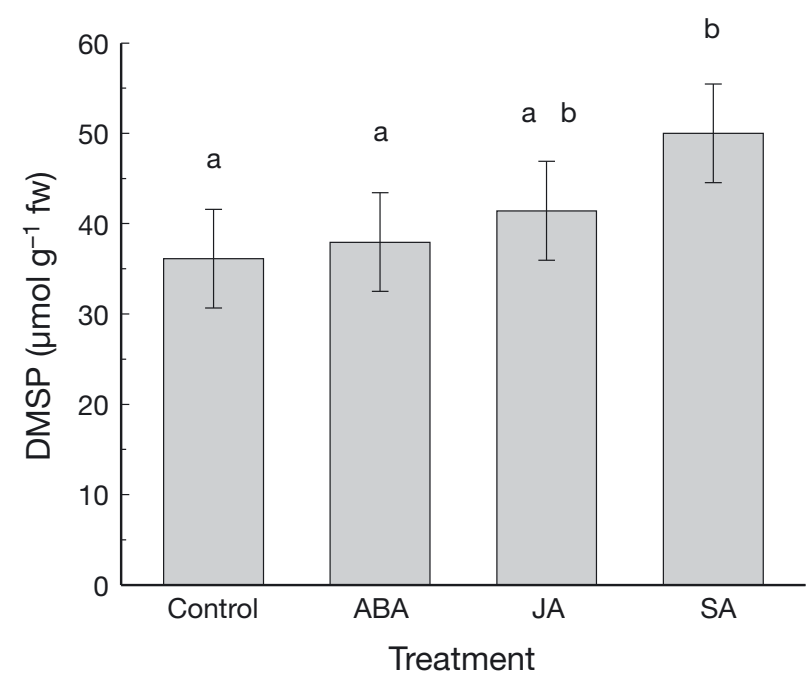

Fig. 2. DMSP concentration ( $\mu \mathrm{mol} \mathrm{g}{ }^{-1}$ fresh weight Spartina alterniflora) for control, abscisic acid (ABA), jasmonic acid (JA), and salicylic acid (SA) treatments (bars are $\pm 1 \mathrm{SD}$ )

$41.4 \pm 5.1 \mu \mathrm{mol} \mathrm{g}{ }^{-1} \mathrm{fw}$. Plants treated with ABA had an average concentration of $38.0 \pm 6.8 \mu \mathrm{mol} \mathrm{g}{ }^{-1} \mathrm{fw}$ and those treated with the control solution had an average DMSP concentration of $36.1 \pm 4.3 \mu \mathrm{mol} \mathrm{g}^{-1}$ fw.

\section{Acute dieback transects}

Average DMSP concentration calculated for individual transect quadrats and non-transect quadrats ranged from $15.0 \mu \mathrm{mol} \mathrm{g}{ }^{-1} \mathrm{fw}$ for plants growing inside the dieback to $51.7 \mu_{\mathrm{mol} \mathrm{g}}^{-1} \mathrm{fw}$ in plants $12 \mathrm{~m}$ from the dieback edge in apparently healthy marsh. Average DMSP concentrations increased significantly $(p=0.005)$ with distance from the dieback edge into healthy marsh (Table 1, Fig. 3). Spartina alterniflora biomass ranged from $229 \mathrm{~g} \mathrm{~m}^{-2}$ at the edge of the dieback to $853 \mathrm{~g} \mathrm{~m}^{-2}$ at $14.9 \mathrm{~m}$ from the edge and was not significantly correlated with distance, but was significantly $(p=0.002)$ correlated with snail density (Table 1, Fig. 4).

Snail density ranged between 0 ind. $\mathrm{m}^{-2}$ inside and at the dieback edge to 160 ind. $\mathrm{m}^{-2}$ at $8 \mathrm{~m}$ from the

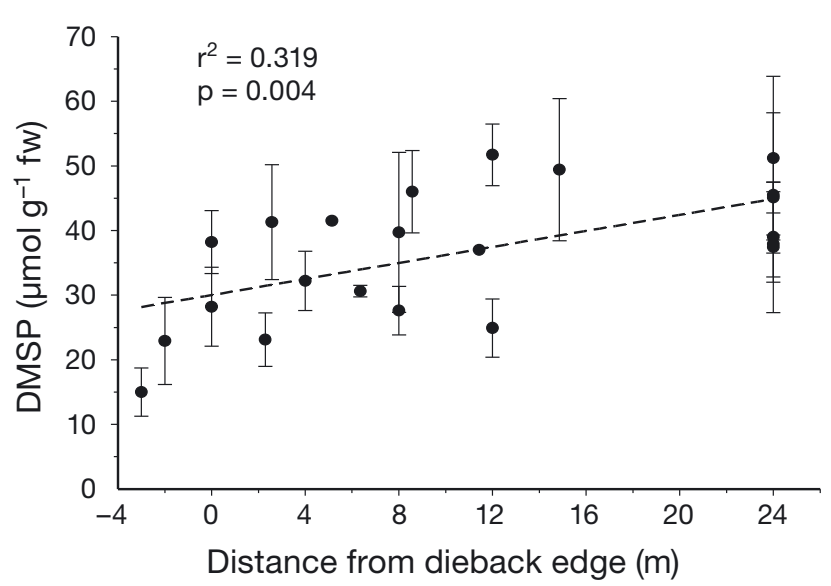

Fig. 3. Distance from the dieback edge $(\mathrm{m})$ and average DMSP concentration ( $\mu \mathrm{mol} \mathrm{g}^{-1}$ fresh weight Spartina alterniflora) calculated for individual quadrats (black dots) at a dieback site. Dotted line: best fit

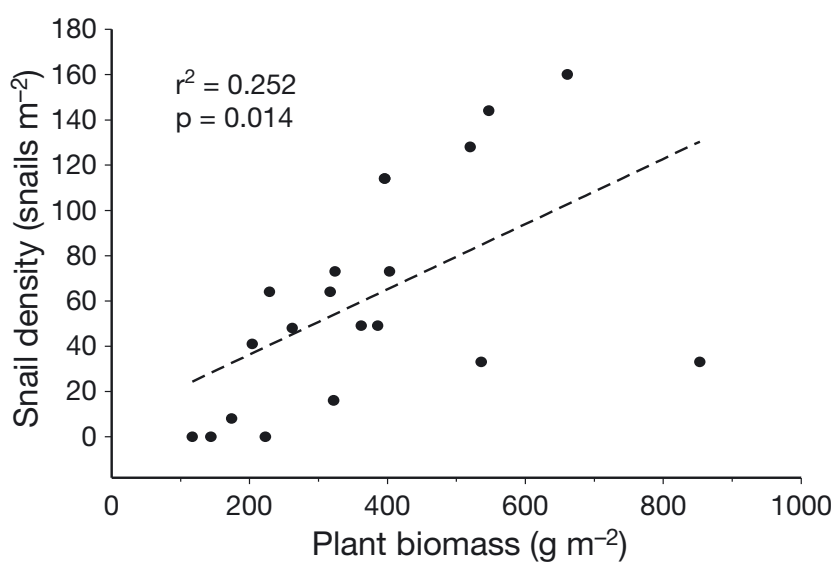

Fig. 4. Spartina alterniflora and Littoraria irrorata. Plant biomass $\left(\mathrm{g} \mathrm{m}^{-2}\right)$ and snail density (ind. $\left.\mathrm{m}^{-2}\right)$ measured for individual quadrats (black dots) at a dieback site. Dotted line: best fit

dieback edge. Density varied significantly with distance from the dieback edge, but it was not significantly correlated with average DMSP concentration (Table 1). The ratio of snail density to plant biomass (snails $\mathrm{g}^{-1}$ Spartina alterniflora) also varied significantly with distance (Table 1, Fig. 5). However, further

Table 1. Variable correlation matrix among average foliar DMSP concentration ( $\mu \mathrm{mol} \mathrm{g} \mathrm{g}^{-1}$ fresh weight Spartina alterniflora), snail density (snails $\mathrm{m}^{-2}$ of marsh), plant biomass $\left(\mathrm{g} \mathrm{m}^{-2}\right.$ of marsh), and the ratio of snail density to plant biomass (snails $\mathrm{g}^{-1}$ Spartina alterniflora) for combined dieback data. Bold: significant

\begin{tabular}{|c|c|c|c|c|c|c|c|c|c|}
\hline & \multicolumn{3}{|c|}{ Distance } & \multicolumn{3}{|c|}{ Mean (DMSP) } & \multicolumn{3}{|c|}{ Snail density } \\
\hline & $\mathrm{r}$ & $\mathrm{p}$ & $\mathrm{N}$ & $\mathrm{r}$ & $\mathrm{p}$ & $\mathrm{N}$ & $\mathrm{r}$ & $\mathrm{p}$ & $\mathrm{N}$ \\
\hline Mean (DMSP) & 0.579 & 0.005 & 22 & - & - & - & - & - & - \\
\hline Snail density & 0.527 & 0.012 & 22 & 0.177 & 0.431 & 22 & - & - & - \\
\hline Snail density:plant biomass & 0.504 & 0.017 & 22 & 0.045 & 0.843 & 22 & - & - & - \\
\hline Plant biomass & 0.411 & 0.072 & 20 & 0.313 & 0.179 & 20 & 0.661 & 0.002 & 20 \\
\hline
\end{tabular}




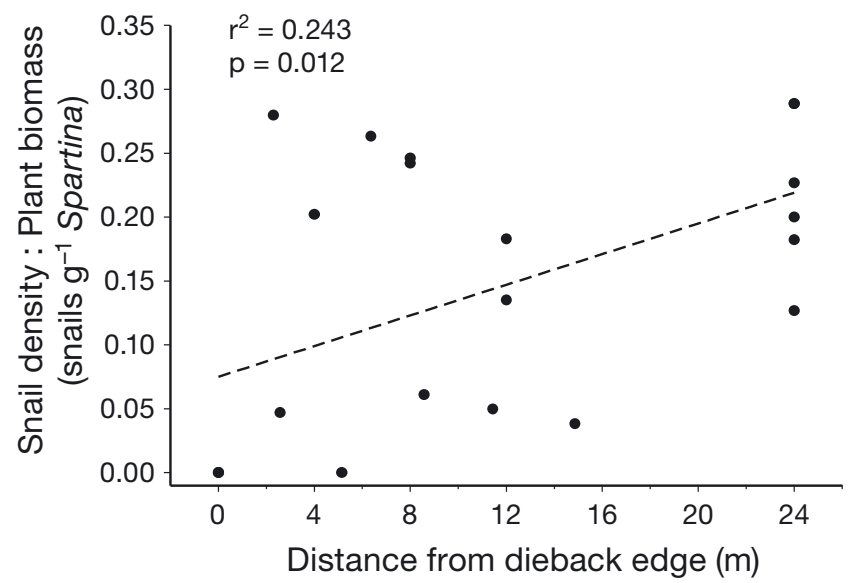

Fig. 5. Spartina alterniflora and Littoraria irrorata. Distance from the dieback edge $(\mathrm{m})$ and the ratio of snail density to plant biomass (no. snails $\mathrm{g}^{-1} S$. alterniflora) measured for individual quadrats (black dots) at a dieback site. Dashed line: best fit

analysis indicated that the slope of a regression of snail density versus distance was not significantly different from $0\left(F_{1,20}=3.9, \mathrm{p}=0.064\right)$. Overall chloride concentrations measured at the dieback site were significantly higher than those at Goat Island and Oyster Landing (Bonferroni, $F_{2,217}=6.5, \mathrm{p}=0.002$ ).

\section{Ring assay}

There was a significant relationship between treatment (DMSP concentration) and snail response (positive, negative, or neutral) upon encountering the test ring $\left(\chi^{2}=11.6, \mathrm{df}=4, \mathrm{p}=0.021\right)$. For the control, 10, and $90 \mu \mathrm{mol} \mathrm{ml} \mathrm{m}^{-1}$ treatments, 95, 80, and $60 \%$, respectively, of snails exhibited a neutral behavior upon encountering the test ring. Zero, 20, and $40 \%$ of snails exhibited a positive behavior for the control, 10, and $90 \mu \mathrm{mol} \mathrm{ml}{ }^{-1}$ treatments, respectively. One snail in the control treatment exhibited a negative behavior upon encountering the test ring.

\section{DISCUSSION}

Exogenous application of ABA or JA did not result in significant changes in foliar concentrations of DMSP in Spartina alterniflora, while SA application resulted in a significantly elevated concentration ( $p<0.05$; Fig. 2). Because DMSP concentration increased in response to SA application, we conclude that DMSP production or transformation in $S$. alterniflora is linked to the SA signaling pathway. SA is a rapidly-translocatable compound that can induce a variety of physiological responses in plants ranging from flowering to thermo- tolerance (see Raskin 1992 for review). While we do not know which physiological changes SA induces in $S$. alterniflora, the roles of this hormone in pathogen defense (Shah 2003), disease resistance (Raskin 1992), and physiological response to osmotic stress (Borsani et al. 2001) in other plants suggest potential roles for SA in S. alterniflora. DMSP's link to the SA pathway in $S$. alterniflora suggests that DMSP may also be involved in these or other SA-related functions. Although we did not observe a change in DMSP concentration in response to ABA or JA exposure, we cannot determine if DMSP production and/or transformation are linked to the ABA and/or JA signaling pathways. It is possible that we missed a DMSP response to ABA or JA exposure, because we sampled DMSP concentration only once, $3 \mathrm{~d}$ after the first hormone exposure. Foliar concentrations of DMSP increased significantly with increasing distance from the dieback edge (Fig. 3). Concentrations near the dieback in apparently healthy marsh were within the 27.0 to $63.1 \mu \mathrm{mol} \mathrm{g}{ }^{-1}$ range that was found in healthy $S$. alterniflora growing in non-dieback areas elsewhere in North Inlet estuary (Pate 2008). However, foliar DMSP concentrations in plants inside and near the dieback were atypically low. The elevation of the dieback is lower than the surrounding marsh (Fig. 1a) and is often waterlogged (pers. obs.). Waterlogging can lead to increased sulfide concentration and to extended periods of anaerobic root metabolism, conditions which are physiological stressful and reduce $S$. alterniflora growth at dieback sites (Mendelssohn \& McKee 1988). Additionally, the North Inlet dieback site experienced elevated porewater salinity during our study period. Elevated salinity is sometimes associated with dieback and can lead to decreased S. alterniflora growth (Brown et al. 2006, Marsh 2007). These stressful edaphic conditions probably led to lowered foliar DMSP concentration in plants growing in or near the dieback.

Because we expected DMSP to deter periwinkle snails and we observed a positive correlation between DMSP concentration and distance from the dieback edge, we expected that Littoraria irrorata density would decrease with increasing distance from the dieback edge. Our observations do not support this hypothesis. Snail density varied significantly with plant biomass (Fig. 4) and with distance from the dieback edge; however, snail density did not vary with DMSP concentration (Table 1). These results suggest that plant biomass may play a more important role as a determinant of snail density than DMSP concentration. An observation that may support the role of DMSP as a snail attractant is that the ratio of snail density to plant biomass (snails $\mathrm{g}^{-1}$ Spartina alterniflora) increased with distance from the dieback edge (Fig. 5). Whether relatively high DMSP concentrations in S. alterniflora 
growing farther from the dieback edge led to a shift in L. irrorata distribution is unknown, as predation (Silliman et al. 2004) or physical factors (Canepuccia et al. 2007) may have contributed to the observed pattern. However, the relatively high ratio of snail density to plant biomass suggests an influence on snail density beyond that of plant biomass. That DMSP may act as an L. irrorata attractant and not as a deterrent is further supported by the results of the ring assay. Twenty percent and $40 \%$ of $L$. irrorata were attracted to $10 \mu \mathrm{mol}$

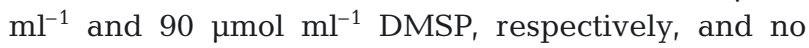
snails exhibited a negative behavior.

Previous investigators have focused on the production, function, and fate of DMSP in Spartina alterniflora (Pakulski \& Kiene 1992, Otte \& Morris 1994, Otte et al. 2004), but none have shown that DMSP concentration affects Littoraria irrorata behavior as this study has. The ring assay showed that periwinkle snails are attracted to elevated levels of DMSP. There are a number of potential explanations for why this occurs. First, DMSP may be a signaling cue for L. irrorata to the location of S. alterniflora, an important habitat resource for L. irrorata. S. alterniflora is also an important food resource for L. irrorata. Periwinkle snails feed on detrital S. alterniflora (Alexander 1976) and on fungi associated with live plants (Silliman \& Newell 2003). Some salt marsh fungi contain DMSP lyase, which is used to convert DMSP to DMS (Bacic et al. 1998, Bacic \& Yoch 1998). DMSP may benefit snails by providing a chemical substrate on which their fungal food can grow.

Drought, elevated salinity, grazing, waterlogging, and pathogenic infection have all been observed in conjunction with salt marsh dieback (Alber et al. 2008). At least some of these factors may lead to production or localization of SA in certain plant tissues, followed by associated biochemical and physiological reactions (Raskin 1992). While SA in Spartina alterniflora has not been studied, certain conditions connected with salt marsh dieback may trigger similar reactions and may lead to changes in DMSP concentration. Fluctuations in DMSP concentration may, in turn, influence Littoraria irrorata behavior or distribution near dieback areas. While we cannot confirm or disprove the full chain of causal relationships beginning with marsh dieback, leading to changes in SA, DMSP, and ultimately to the behavior of $L$. irrorata populations, our study does support individual pieces of this model. Moreover, our work raises a number of new questions. For example, do SA concentrations in S. alterniflora react to dieback conditions? How variable is SA concentration and does DMSP concentration respond similarly? Do fluctuating DMSP concentrations have a significant impact on L. irrorata distributions in the marsh, or are other factors such as plant biomass and plant density more important?
By controlling the growth of Spartina alterniflora, an important food and habitat resource, edaphic conditions such as drought or nutrient availability may exert control of primary, secondary, and highertrophic-level consumer populations (Ngai \& Jefferies 2004, Valiela et al. 2004, Fleeger et al. 2008, Frost et al. 2009). While this study does not necessarily support a model of direct control of salt marsh production and dieback by drought, our results are consistent with a model of indirect response by consumer populations to edaphic conditions. For example, changes in soil conditions may lead to fluctuations in $S$. alterniflora DMSP concentration and influence when, where, and to what extent Littoraria irrorata snails congregate. By affecting the location and density of snails, DMSP concentration in $S$. alterniflora may affect the availability of $L$. irrorata to higher trophic levels. Future research efforts should focus on the links between soil condition, SA, DMSP, L. irrorata, and potential trophic effects.

Acknowledgements. We thank W. Wang, J. Buschur, M. Day, and K. Sundberg for their assistance with data collection in the field and laboratory, and S. Scott for generating the elevation map. We also thank the anonymous reviewers whose critiques greatly improved this manuscript. This study was supported by grants from NSF, NOAA, and the Slocum-Lunz Foundation.

\section{LITERATURE CITED}

Alber M, Swenson EM, Adamowicz SC, Mendelssohn IA (2008) Salt marsh dieback: an overview of recent events in the US. Estuar Coast Shelf Sci 80:1-11

Alexander SD (1976) Relationship of macrophyte detritus to the salt marsh periwinkle, Littoraria irrorata (Say). PhD dissertation, Louisiana State University, Baton Rouge, LA Antoniw JF, White RF (1980) The effects of aspirin and polyacrylic acid on soluble leaf proteins and resistance to virus infection in five cultivars of tobacco. Phytopathology 98: 331-341

> Bacic MK, Yoch DC (1998) In vivo characterization of dimethylsulfoniopropionate lyase in the fungus Fusarium lateritium. Appl Environ Microbiol 64:106-111

Bacic MK, Newell SY, Yoch DC (1998) Release of dimethylsulfide from dimethylsulfoniopropionate by plant-associated salt marsh fungi. Appl Environ Microbiol 64:1484-1489

Borsani O, Valpuesta V, Botella MA (2001) Evidence for a role of salicylic acid in the oxidative damage generated by $\mathrm{NaCl}$ and osmotic stress in Arabidopsis seedlings. Plant Physiol 126:1024-1030

Bradford KJ (1983) Water relations and growth of the flacca tomato mutant in relation to abscisic acid. Plant Physiol 72: 251-255

> Brown CE, Pezeshki SR, DeLaune RD (2006) The effects of salinity and soil drying on nutrient uptake and growth of Spartina alterniflora in a simulated tidal system. Environ Exp Bot 58:140-148

Canepuccia AD, Escapa M, Daleo P, Alberti J, Botto F, Iribarne OO (2007) Positive interactions of the smooth cordgrass Spartina alterniflora on the mud snail Heleobia aus- 
tralis, in South Western Atlantic salt marshes. J Exp Mar Biol Ecol 353:180-190

Chambers ST, Kunin CM, Miller D, Hamada A (1987) Dimethylthetin can substitute for glycine betaine as an osmoprotectant molecule for Escherichia coli. J Bacteriol 169:4845-4847

> Colmer TD, Fan TWM, Lauchli A, Higashi RM (1996) Interactive effects of salinity, nitrogen and sulphur on the organic solutes in Spartina alterniflora leaf blades. J Exp Bot 47:369-375

Creelman R, Mullett J (1995) Jasmonic acid distribution and action in plants: regulation during development and response to biotic and abiotic stress. Proc Natl Acad Sci USA 92:4114-4119

Dacey JWH, Wakeham SG (1986) Oceanic dimethylsulfide: production during zooplankton grazing on phytoplankton. Science 233:1314-1316

Dacey JWH, King GM, Wakeham SG (1987) Factors controlling emission of dimethylsulphide from salt marshes. Nature 330:643-645

$>$ Dat JF, Foyer CH, Scott IM (1998) Changes in salicylic acid and antioxidants during induced thermotolerance in mustard seedlings. Plant Physiol 118:1455-1461

Dat JE, Lopez-Delgado H, Foyer CH, Scott IM (2000) Effects of salicylic acid on oxidative stress and thermotolerance in tobacco. J Plant Physiol 156:659-665

> DeBose JL, Lema SC, Nevitt GA (2008) Dimethylsulfoniopropionate as a foraging cue for reef fishes. Science 319:1356

> Duval MA, Calzetta AM, Rittschof D (1994) Behavior response of Littoraria irrorata (SAY) to water-borne odors. J Chem Ecol 20:3321-3334

> Farmer EE, Ryans CA (1990) Interplant communication: airborne methyl jasmonate induces synthesis of proteinase inhibitors in plant leaves. Proc Natl Acad Sci USA 87:7713-7716

Fleeger JW, Johnson DS, Galvan KA, Deegan LA (2008) Topdown and bottom-up control of infauna varies across the saltmarsh landscape. J Exp Mar Biol Ecol 357:20-34

Fodor J, Gullner G, Adam AL, Barna B, Komives T, Kiraly Z (1997) Local and systemic responses of antioxidants to tobacco mosaic virus infection and to salicylic acid in tobacco. Plant Physiol 114:1443-1451

Frost JW, Schleicher T, Craft C (2009) Effects of nitrogen and phosphorus additions on primary production and invertebrate densities in a Georgia (USA) tidal freshwater marsh. Wetlands 29:196-203

> Husband JD, Kiene RP (2007) Occurrence of dimethylsulfoxide in leaves, stems and roots of Spartina alterniflora. Wetlands 27:224-229

Karsten U, Wiencke C, Kirst GO (1990) The $\beta$-dimethylsulphoniopropionate (DMSP) content of macroalgae from Antarctica and southern Chile. Bot Mar 33:143-146

Larkindale J, Knight MR (2002) Protection against heat stressinduced oxidative damage in Arabidopsis involves calcium, abscisic acid, ethylene and salicylic acid. Plant Physiol 128: 682-695

Lopez-Delgado H, Dat JF, Foyer CH, Scott IM (1998) Induction of thermotolerance in potato microplants by acetylsalicylic acid and $\mathrm{H}_{2} \mathrm{O}_{2}$. J Exp Bot 49:713-720

Marsh A (2007) Effects on a salt marsh ecosystem following a brown marsh event. MS thesis, East Carolina University, Greenville, NC

> McKee K, Mendelssohn I, Materne M (2004) Acute salt marsh dieback in the Mississippi River deltaic plain: a droughtinduced phenomenon? Glob Ecol Biogeogr 13:65-73

Mendelssohn IA, McKee KL (1988) Spartina alterniflora dieback in Louisiana: time-course investigation of soil waterlogging effects. J Ecol 76:509-521
Mizrahi Y, Blumenfeld A, Richmond AE (1970) Abscisic acid and transpiration in leaves in relation to osmotic root stress. Plant Physiol 46:169-171

> Morris JT, Sundararwshwar PV, Nietch CT, Kjerfve B, Cahoon DR (2002) Response of coastal wetlands to rising sea level. Ecology 83:2869-2877

Nakajima K (1989) Effects of high concentrations of dimethylt-hetin, dimethyl- $\beta$-propiothetin and vitamin $U$ on young rats. Mem Koshien Univ 17:1-8

- Ngai JT, Jefferies RL (2004) Nutrient limitation of plant growth and forage quality in Arctic coastal marshes. J Ecol 92:1001-1010

Ogburn MB, Alber M (2006) An investigation of salt marsh dieback in Georgia using field transplants. Estuar Coast 29:54-62

> Otte ML, Morris JT (1994) Dimethylsulphoniopropionate (DMSP) in Spartina alterniflora Loisel. Aquat Bot 48: 239-259

Otte ML, Wilson G, Morris JT, Moran BM (2004) Dimethylsulphoniopropionate (DMSP) and related compounds in higher plants. J Exp Bot 55:1919-1925

Pakulski JD, Kiene RP (1992) Foliar release of dimethylsulfoniopropionate from Spartina alterniflora. Mar Ecol Prog Ser 81:277-287

Pate WM (2008) Relationships among Spartina alterniflora, Littoraria irrorata, and dimethylsulfoniopropionate (DMSP). MS thesis, University of South Carolina, Columbia

Rao MV, Paliyath G, Ormrod P, Murr DP, Watkins CB (1997) Influence of salicylic acid on $\mathrm{H}_{2} \mathrm{O}_{2}$ production, oxidative stress, and $\mathrm{H}_{2} \mathrm{O}_{2}$-metabolizing enzymes. Plant Physiol 115: $137-149$

Raskin I (1992) Role of salicyclic acid in plants. Annu Rev Plant Physiol Plant Mol Biol 43:439-463

> Raskin I, Ehmann A, Melander WR, Meeuse BJD (1987) Salicylic acid - a natural inducer of heat production in Arum lilies. Science 237:1601-1602

> Raskin I, Turner IM, Melander WR (1989) Regulation of heat production in the flourescences of an Arum lily by endogenous salicylic acid. Proc Natl Acad Sci USA 86: $2214-2218$

> Senaratna T, Touchell D, Bunn E, Dixon K (2000) Acetyl salicylic acid (Aspirin) and salicylic acid induce multiple stress tolerance in bean and tomato plants. Plant Growth Regul 30:157-161

- Shah J (2003) The salicylic acid loop in plant defense. Curr Opin Plant Biol 6:365-371

Silliman BR, Newell SY (2003) Fungal farming in a snail. Proc Natl Acad Sci USA 100:15643-15648

Silliman BR, Layman CA, Geyer K, Zieman JC (2004) Predation by the black-clawed mud crab, Panopeus herbstii, in Mid-Atlantic salt marshes: further evidence for top-down control of marsh grass production. Estuaries 27:188-196

Silliman BR, Koppel JVD, Bertness MD, Stanton LE, Mendelssohn IA (2005) Drought, snails, and large-scale die-off of southern U.S. salt marshes. Science 310:1803-1806

Srivastava MK, Dwivedi UN (1998) Salicylic acid modulates glutathione metabolism in pea seedlings. J Plant Physiol 153:409-414

Sunda W, Kieber DJ, Huntsman S (2002) An antioxidant function for DMSP and DMS in marine algae. Nature 418 : $317-320$

Sundareshwar PV, Morris JT, Koepfler E, Fornwalt B (2003) Phosphorous limitation of coastal ecosystem processes. Science 299:563-565

Valiela I, Rutecki D, Fox S (2004) Salt marshes: biological controls of food webs in a diminishing environment. J Exp Mar Biol Ecol 300:131-159 
Van Alstyne KL, Houser LT (2003) Dimethylsulfide release during macroinvertebrate grazing and its role as an activated chemical defense. Mar Ecol Prog Ser 250:175-181

> Van Alstyne KL, Wolfe GV, Friedenberg TL, Neill A, Hicken C (2001) Activated chemical defense systems in marine macroalgae: evidence for an ecological role for DMSP cleavage. Mar Ecol Prog Ser 213:53-65

Van Diggelen J, Rozema J, Broekman R (1986) Growth and mineral relations of salt marsh species on nutrient solutions containing various sodium sulphide concentrations. In: Huiskes AHL, Bloom CWPM, Rozema J (eds) Vegetation between land and sea. W. Junk, Dordrecht, p 260-268

Ward ER, Uknes SJ, Williams SC, Dincher SS and others (1991) Coordinate gene activity in response to agents that induce systematic acquired resistance. Plant Cell 3:1085-1094

Editorial responsibility: Hans Heinrich Janssen, Oldendorf/Luhe, Germany
White RF (1979) Short communications: acetylsalicylic acid (asprin) induces resistance to tobacco mosaic virus in tobacco. Virology 99:410-412

Wieringa-Brants DH, Schets FM (1988) Effect of salicylic acid and phenylserine on the hypersensitive reaction of tobacco to tobacco mosaic virus. J Phytopathol 123: 333-343

Wolfe GV, Steinke M (1996) Grazing-activated production of dimethylsulfide (DMS) by two clones of Emiliania huxleyi. Limnol Oceanogr 41:1151-1160

> Wolfe GV, Steinke M, Kirst GO (1997) Grazing-activated chemical defense in a unicellular marine alga. Nature 387: 894-897

Zabadal T (1974) A water potential threshold for the increase of abscisic acid in leaves. J Plant Physiol 53:125-127

Submitted: July 30, 2009; Accepted: February 18, 2010

Proofs received from author(s): April 28, 2010 